\title{
FORMULA JELLY DRINK CINCAU HIJAU, PANDAN WANGI DAN KAYU MANIS UNTUK MENURUNKAN KADAR GULA DARAH PENDERITA DIABETES MELITUS
}

\author{
ZaenalAmirudin*, RosmiatiSaleh, Afiyah Sri Harnany \\ Program Studi Diploma III Keperawatan Pekalongan Poltekkes Kemenkes Semarang \\ Jl. Perintis Kemerdekaan Pekalongan
}

Koresponden: zaenalamirudin@gmail.com

\begin{abstract}
Background: Treatment of diabetes mellitus has been in the form of insulin injections and oral antidiabetic drugs. Green grass jelly leaves, fragrant pandanus and cinnamon are herbal plants that can be developed into jelly drinks as a therapeutic-based functional food to prevent the risk of diabetes mellitus. The purpose of this study was to make jelly drink made from green grass jelly, fragrant pandanus and cinnamon and its effect on blood glucose levels. Methods: The study began with a hedonic organoletic test to determine the selected jelly drink formula for 20 panelists. Followed by the experimental method of Pretest-Postest Group Design. Results: organoleptic test in the most preferred product with a comparison of green cincau leaves: fragrant pandan leaves $(90: 10 / \mathrm{v}$ : v) plus $0.5 \%$ cinnamon filtrate and 0.5 gram stevia sugar. The average blood glucose level in the control group decreased on days 14 and 21. The ANOVA test results showed no significant difference in the decrease in blood glucose levels between groups ( $\square$ value $0.124>0.05$ ). The average blood glucose level in the intervention group experienced a decrease in days 7, 14 and 21. The ANOVA test results showed that there were significant differences between groups ((value $0.001<0.05)$. The decrease in blood glucose levels was more effective in the intervention group given jelly drink than in the control group given green grass jelly. Suggestion: It is necessary to do further research to determine the dose of flavonoids which is effective in reducing blood glucose levels in the green jelly jelly drink products
\end{abstract}

Keywords: Jelly drink, Food based therapy, Diabetes mellitus

\section{PENDAHULUAN}

Prevalensi penyakit diabetes melitus terus meningkat secara signifikan pada beberapa tahun terakhir ini. Hasil Riset Kesehatan Dasar (Riskesda, 2013) menyebutkan bahwa penyakit diabetes millitus (DM) mencapai $2,1 \%$ per seribu penduduk dan menduduki peringkat ke-2 penyebab kematian, yakni $14,7 \%$.

Pengobatan diabetes melitus selama ini berupa obat suntikan insulin dan obat antidiabetik oral, selain harganya relatif mahal juga dapat memberikan efek samping

Saat ini banyak dikembangkan pangan atau minuman fungsional berbasis terapi (food based therapy) yang berasal dari tanaman herbal untuk mencegah risiko terhadap penyakit degeratiff seperti diabetes melitus.

Hasil penelitianpada skala laboratorium membuktikan daun cincau hijau (Cylea barbara miers), daun pandan (Pandanus amaryllifolius), dan kayu manis (Cinnamomum burmannii), memiliki potensi untuk dijadikan pangan fungsional berbasis terapi. Ketiga tanaman herbal tersebut selain mudah didapat, juga mengandung senyawa bioaktif seperti alkaloid, siklein, tetrandrin, dimetil tetrandin, polifenol, sapanoid, dan flavonoid yang dapat berfungsi sebagai antioksidan dan flavor (Prajwalita R.R, Rizca D.J, Tri Dewanti W, 2015)., serta memiliki aroma yang baik (Rohmati E, 1995)

Pada penelitian ini daun cincau hijau akan diformulasikan dengan daun pandan wangi dan kayu manis menjadi produk inovasi jelly drink yang dapat menurunkan kadar glukosa darah. 


\section{Rumusan Masalah}

Berdasarkan uraian tersebut di atas, maka dapat dibuat perumusan masalah sebagai berikut:

2.1. Apakah cincau hijau, pandan wangi dan kayu manis dapat diolah menjadi produk inovatif jelly drink sebagai minuman fungsional yang memiliki tektur, konsisten baik?

2.2. Apakah produk jelly drink cincau hijau, pandan wangi dan kayu manis dalam kemasan cup dapat meningkatkan produktivitas produksi?

2.3. Dapatkah jelly drink cincau hijau diminati konsumen dan menambah pengahasilan dan kesejahteraan masyarakat?

\section{Kajian Pustaka}

\subsection{Cincau Hijau}

Dikenal ada tiga jenis tanaman cincau, yaitu cincau hijau (Cyclea barbata Miers), cincau hijau perdu (Premna parasitica Blume), cincau hitam (Mesona palustris $B$ ). Secara Umum yang dikenal masyarakat ada dua jenis cincau, yaitu cincau hitam dan cincau hijau.

Secara umum kandungan kimia daun cincau hijau adalah karbohidrat, lemak, protein, klorofil, dan senyawa seperti polifenol, flavonoid, serta mineral dan vitamin diantaranya fosfor, vitamin A dan vitamin B (Djam'an, 2008). Kandungan lainnya adalah alkaloid bisbenzilisokuinolin, seperti tetradrin, fangkinolin, barbamin, homoaromolin, sikleapeltin, dan sikleabarbatin (De Padua, Bunyapraphatsara, dan Lemmens, 1999) dalam Ali, M.H (2012).

Cincau banyak dimanfaatkan oleh masyarakat secara tradisional sebagai penurun panas badan, obat panas dalam, obat sakit perut (mual) dan obat diare (Setijo, 1998). Selain itu, akar cincau mempunyai khasiat sebagai antimalaria dan mempunyai aktivitas sitotoksik karena mengandung bisbenzylisoquinoline (Angerhofer et al, 1999). Tanaman cincau juga dimanfaatkan sebagai makanan bagi yang sedang melakukan diet karena nilai kalorinya yang rendah.

Hasil studi empiris yang pernah dilakukan oleh Nurdin et al. (2005) menunjukkan bahwa daun cincau hijau mengandung serat pektin dan aktivitas antioksidan yang sangat tinggi. Miladiyah dan Siregar (2011) membuktikan bahwa daun cincau memiliki aktivitas anti radang lambung. Selain itu, Lokesh Amitsankar (2012), menyatakan bahwa kandungan zat aktif flavonoid dapat berperan sebagai anti-hepatotoksik, anti-HIV 1, anti inflamasi dan dapat memberikan efek vasodilatasi terhadap pembuluh darah yang membantu melindungi fungsi jantung. Curtis et al. (2013) Fitriana S, Leiley A, dan karina R.E. (2014, menunjukkan bahwa flavonoid dapat menurunkan kekakuan arteri dan dapat mengurangi risiko penyakit jantung pada pasien diabetes militus yang telah menopause.

\subsection{Pandan Wangi}

Tanaman pandan wangi (Pandanus amaryllifolius) termasuk genus Pandanus, dan famili Pamdanaceae. Tanaman ini tumbuh di daerah tropis dan merupakan tanaman perdu tahunan dengan tinggi 1-2 meter.

Tanaman ini dimanfaatkan sebagai rempah-rempah, bahan penyedap, pewangi dan pemberi warna hijau pada makanan, serta bahan baku pembuatan minyak wangi. Pandan juga dimanfaatkan sebagai obat tradisional untuk mencegah 
rambut rontok, menghitamkan rambut, menghilangkan ketombe, mengobati lemah saraf, tidak nafsu makan, rematik. Kandungan kimia daun pandan antara lain alkaloida, saponin, flavanoid, tanin, polifenol, zat warna (Rohmati E, 1995).

Hasil studi sebelumnya menunjukkan bahwa daun pandan mengandung 2acetyl-1-pyrroline (2-AP), kandungan lainnya adalah minyak volatil, alkohol, senyawa aldehid aromatik, keton dan ester (Laksanamai V. and Ilangantileke S. 1993). Fatihanim M.N., Suhaila M., Nor A.I., and Razali I. (2008), membuktikan bahwa ekstrak daun pandan dapat berperan sebagai antioksidan alami. Daun pandan memiliki kandungan polifenol dan berperan sebagi antioksidan yang tahan panas sehingga berpotensi sebagai antioksidan alami.

Daun pandan secara luas telah digunakan sebagai pemberi rasa pada makanan. Ekstraknya digunakan untuk sebagai essesce pada industri kue dan seluruh bagian daunnya membuat nasi lemak di Malaysia, nasi kuning di Indonesia. Di negara India dan Filipina menggunakan daun pandan secara tradisional untuk memasak nasi non-aromatik untuk menguatkan aromanya. Selain itu, tanaman ini juga digunakan sebagai obat tradisional untuk meredakan sakit gigi, rematik, diuretik, antiinflamasi, dan menurunkan kadar gula darah dalam tubuh atau efek hipoglikemik (Asmain A.B., 2010, dalam Winda Rein. N.T, Tri Dewanti W., (2014).

\subsection{Kayu Manis (Cinnamomum burmannii)}

Kayu manis merupakan tanaman asli Asia Selatan, Asia Tenggara, dan daratan Cina termasuk Indonesia. Tanaman ini termasuk famili Lauraceae yang merupakan tanaman tahunan dan memiliki nilai ekonomi. Hasil utamannya adalah kulit batang dan dahan, sedang hasil lainnya adalah ranting dan daun. Komoditas kayu manis selain sebagai rempah, hasil olahannya berupa minyak atsiri dan oleoresin banyak digunakan dalam industri farmasi, kosmetik, makanan dan minuman, rokok (Heyne K., 1987) dalam Winda R.N.T, Tri Dewanti W., (2014).

Kayu manis mengandung minyak atsiri, eugenol, safrole, sinamaldehid, tanin, kalsium oksalat, damar, dan zat penyamak (Thomas J. and Duethi P.P. 2001) dalam Winda R.N.T, Tri Dewanti W., (2014). Selain itu, kayu manis juga mengandung protein, katbohidrat, vitamin (A, C, K, B3), mineral seperti kalsium, zat besi, magnesium, mangan, fosfor, sodium, zinc dan kolin (Meena V., Sree S.N., Surya P.D.V., and Sumanjali A., 2012) dalam Winda R.N.T, Tri Dewanti W., (2014).

Hasil penelitian Gupta, Charu, Garg A.P, Uniyal R.C., and Kumari A. (2008) dalam Winda R.N.T, Tri Dewanti W., (2014), menunjukkan bahwa minyak atsiri kayu manis mengandung senyawa sinamaldehid dan asam sinnamat sangat efektif menghambat pertumbuhan beberapa bakteri antara lain B. Cereus, S. Aureus, E. Coli, P. Aeruginosa dan Klebsiella sp. Selain itu, menurut Soemardini dkk (2011), kayu manis telah diteliti beberapa kali dapat menurunkan kadar glukosa darah, total kolesterol, dan kadar trigliserida, serta dapat meningkatkan HDL. Kulit kayu manis mengandung alkaloid, flavonoid, dan minyak atsiri yaitu kamfer, safrol, eugenol, sinamaldehid, sinamilasetat, terpen, sineol, sitral, sitronelal, polifenol dan benzaldehid.

\subsection{Minuman Fungsional}

Minuman fungsional memiliki banyak manfaat dan kegunaan secara alami dan mengandung sejumlah senyawa organik. Beberapa bersifat sebagai stimulan 
dan dapat sebagai pengganti kopi, merilekskan pikiran, dapat meningkatkan imun, meredakan gejala demam, dan ada yang untuk meredakan sakit tenggorokan (Vox D., 2011, dalam Winda R.N.T, Tri Dewanti W., (2014).

Pada umumnya efek kesehatan yang diberikan dari minuman fungsional berasal dari kandungan senyawa fenol yang bersifat antioksidan. Beberapa peneliti melaporkan antioksidan dari ekstrak tanaman herbal mampu melawan peroksidasi lipid pada fosfolipid (Naithani V., Nair S., and Kakkar P. 2006), sistem biologis (Guo Q., Zhao B., Li M., Shen S., and Xin W. 1996, dalam Winda R.N.T, Tri Deanti W., (2014), melawan tumorigenesis dan kerusakan DNA (Anderson R.F., Fisher L.J., Hara Y., Harris T., Mak W.B., and Melton L.D. 2001), juga dapat menurunkan tingkat kolesterol, menghambat hipertensi serta mutagenesis (Yokozawa T., Nakagawa T., and Kitani K. 2002, dalam Winda R.N.T, Tri Dewanti W., (2014).

Proses pembuatan minuman fungsional sangat sederhana, bahan-bahan herbal dicampur dengan air mendidih (diseduh). Bahan herbal kering atau segar disiapkan sebanyak 3 gram diseduh dengan air panas (100 derajat Celcius, didiamkan selama 5-10 menit (Moraes-de-Souza R.A., Oldoni T.L.C, Regitanod Arce M.A.B., and Alencar S.M. 2008, dalam Winda R.N.T, Tri Deanti W., (2014), kemudian dikonsumsi. Cara lainnya, yaitu bahan herbal direbus dengan sejumlah air dengan lama waktu tertentu kemudian airnya disaring dan dikonsumsi (Panse S. 2012, dalam Winda R.N.T, Tri Dewanti W., (2014).

\subsection{Jelly Drink}

Jelly merupakan produk minuman semi padat yang terbuat dari sari atau ekstrak buah-buahan atau tumbuh-tumbuhan yang dimasak dalam gula. Gula didalam jelly berfungsi untuk menurunkan tekanan osmotik, sehingga bakteri tidak dapat tumbuh dan produk ini dapat disimpan dalam waktu yang lebih lama, selain itu, juga berfungsi sebagai pengendap pektin. Menurut Widyaningsih (2007), syarat jelly yang baik adalah transparan, memiliki aroma dan rasa yang asli. Sedangkan menurut Triyani (2006), tekstrur yang dinginkan pada minuman jelly adalah mantap saat dikonsumsi menggunakan bantuan sedotan mudah hancur, namun bentuk gelnya masih terasa di mulut.

Glicksman (1993) menyatakan bahwa jelly merupakan produk hasil gelatinasi dari campuran hidrokoloid dan gula dalam air dengan karakteristik gel yang bersifat elastis dan tidak mengandung butiran-butiran halus didalamnya. Sifat fisik penting dengan mutu produk adalah vikositas, kelekatan, elastisitas, plasitisitas, kelenturan, kekenyalan dan sejenisnya (Soekarto, 1995).

\subsection{Glukosa Darah}

Pada keadaan normal kadar gula darah diatur oleh insulin yang diproduksi oleh sel beta pankreas, sehingga kadarnya dalam darah selalu dalam batas normal atau stabil berkisar antara 70-110 mg/dl. Apabila kadar glukosa darah puasa berkisar antara 111-125 mg/dl disebut keadaan glukosa darah yang terganggu atau Impored Flasting Glucose (IFG). Jika kadar glukosa darah tidak normal, tetapi belum termasuk kriteria diabetes melitus, misalnya kadar glukosa darah < 140 $\mathrm{mg} / \mathrm{dl}$, tetapi 2 jam sesudah makan menjadi 140-200 mg/dl, disebut Toleransi Glukosa Terganggu (TGT) atau Impaired Glucose Tolerance (IGT). Jika glukosa darah < $140 \mathrm{mg} / \mathrm{dl}$, tetapi glukosa darah 2 jam setelah konsumsi glukosa 75 gram > 
$200 \mathrm{mg} / \mathrm{dl}$ berarti mengindap diabetes. Kriteria diabetes, meluputi : 1) baik kadar glukosa darah 80-109 mg/dl, 2) sedang 110-139 mg/dl, 3) buruk > $140 \mathrm{mg} / \mathrm{dl}$. Kadar gula darah 2 jam setelah makan kriteria 1) baik 110-159 mg/dl, 2) sedang 160-199 mg/dl, 3) buruk > $200 \mathrm{mg} / \mathrm{dl}$ (Hans Tandra, 2007).

Glukosa darah berasal dari makanan, glukoneogenesis, dan glikogenolisis. Makaanan ketika dikunyah akan bercampur dengan saliva yang teridiri atas enzim pencernaan ptialin yaang dieksresi oleh kelenjar parotis. Enzim ini menghidrolisis karbohidrat menjadi disakarida dan polimer glukosa kecil lainnya. Selanjutnya, pencernaan karbohidrat dilakukan oleh amilase pankreas yang mengandung sejumlah besar alpha amilase. Eritrosit pada vili usus halus mengandung enzim laktase, sukrase dan unsur polimer glukosa kecil menjadi monosakarida, galaktosa, fruktosa, dan glukosa (Guyton and Hall, 2007). Glukosa dan galaktosa diserap oleh transport aktif sekunder, sementara fruktosa diserap ke dalam darah melalui difusi (Sherwood, 2001, dalam feranosa, 2009).

Glukosa dibentuk melalui proses glukoneogenesis dari berbagai senyawa glukogenik. Senyawa ini terdiri atas dua golongan, yaitu senyawa konversi netto langsung menjadi glukosa tanpa daur ulang seperti beberapa asam amino dan propionat. Senyawa hasil metabolisme parsial glukosa dalam jaringan tertentu yang diangkut ke dalam hati dan ginjal untuk disintesis kembali menjadi glukosa, seperti senyawa laktat dan gliserol bebas (Murray et al, 2003 dalam Feranosa, 2009).

Glikogenolisis berarti pemecaahan glikogen yang disimpan sel untuk membentuk kembali glukosa di dalam sel. Setiap molekul glukosa yang berurutan pada masing-masing cabang polimer glikogen dilepaskaan melalui proses fosforilasi yang dikatalis oleh enzim fosforilase (Guyton and Hall, 2007).

Konsentrasi glukosa darah diatur dalam batas-batas yang sempit. Setelah penyerapan makanan, kadar glukosa darah pada manusia berkisar antara 4,5-5,5 mmol/L. Apabila mengkonsumsi makanan yang mengandung karbohidrat kadar tersebut dapat naik menjadi 6,7-7,2 $\mathrm{mmol} / \mathrm{L}$. Proses mempertahankan kadar glukosa yang stabil dalam darah merupakan salah satu mekanisme homeostatis (Guyton and Hall, 2007).

Faktor interna dalam tubuh, seperti enzim glukokinase, insulin, glukagon, hormon pertumbuhan, glukokortikoid, tiroksin, sistem gastrointestinal. Faktor eksterna berupa penurunan dan peningkatan asupan karbohidrat, mempengaruhi kadar gula dalam darah (Price and Wilson, 1995 dalam Feranosa, 2009).

Hormon insulin memiliki peranan pokok dalam pengaturan konsentrasi glukosa darah. Hormon ini dihasilkan oleh sel-sel $\beta$ pada pulau langerhans pankreas dan disekresi ke dalam darah secara langsung pada hiperglikemia. Mekanisme penurunan gula darah oleh insulin meliputi peningkatan laju penggunaan glukosa melalui oksidasi, glikogenesis dan lipolisis. Difusi fasilitatif glukosa ke dalam selsel otot dan sel lemak meningkat, penyimpanan glukosa dalam hati dan otot dalam bentuk glikogen, serta pengambilan glukosa untuk diubah menjadi lemak oleh sel lemak dan sel hati meningkat. Glukagon yang diproduksi oleh sel-sel alfa pulau langerhans pankreas mempunyai pengaruh berkebalikan dengan insulin. Glukagon meningkatkan gula darah melalui peningkatan glikogenolisis dan glukogenolisis (Almatsier, 2001 dalam Feranosa, 2009). 
Terdapat dua metode untuk mengukur glukosa darah, yaitu metode kimiawi dengan memanfaatkan sifat mereduksi glukosa nonspesifik dalam reaksi dengan bahan inhibitor yang dapat berubah warna bila tereduksi. Karena adanya senyawa lain dalam urea, metode ini dapat lebih tinggi 5-15 mg/dl. Metode kedua menggunakan metode enzimatik yang umumnya menggunakan glukosa oksidase atau heksokinase. Enzim ini bekerja spesifik pada glukosa dan tidak pada bahan pereduksi lain (Sacher and Mc Pherson, 2004 dalam Feranosa, 2009).

\subsection{Diabetes Militus (DM)}

Diabetes militus merupakan suatu sindrom dengan terganggunya metabolisme karbohidrat, lemak dan protein yang disebabkan oleh berkurangnya sekresi insulin atau penurunan sensitivitas jaringan terhadap insulin (Guyton and Hall, 2007).

Hilangnya toleransi karbohidrat tersebut diiringi dengan gejala kalsik/ khas DM, antara lain poliuri (banyak buang air kecil), polidipsi (sering merasa haus), polifagi (banyak makan), dan penurunan berat badan. jika telah berkembang penuh secara klinis, DM ditandai dengan hiperglikemia puasa dan postprandial, aterosklerotik, dan penyakit vaskuler mikroangiopati, dan neuropati (Schteingart DE, dalam Hartanto H, Susi N, Wulandari P, Mahanani DA, 2005).

Secara umum dikenal dua tipe DM, yaitu DM tipe 1 dan DM tipe 2. Diabetes militus tipe 1 atau biiasa disebut dengan diabetes tipe IDDM (Insulin Dependent Diabetes Millitus), yaitu penyuakit autoimun secara genetik dengan gejala-gejala menuju proses bertahap perusakan imunologik sel-sel yang memproduksi insulin di pankreas. Diabetes militus tipe 2 atau NIDDM (Non Insulin Dependent Diabetes Millitus), ditandai dengan kelainan sekresi insulin dan kerja insulin (Salzler MJC. Crawford JM, Kumar V, dalam Asroruddin M, Hartatnto H, Darmaniah N, 2007). Faktor risiko DM antara lain stres, merokok, obesitas, hipertensi, kurangnya aktivitas fisik dan rendahnya konsumsi sayur dan buah.

Komplikasi kronik DM dapat terjadi pada semua pembuluh darah, baik pembuluh darah kecil (mikrovaskuler) maupun pembuluh darah besar (makrovaskuler). Komplikasi pada mikrovaskuler berupa penyaki ginjal, retinopati, neuropati dan katarak. Komplikasi makrovaskler yaitu terjadinya gambaran histopatologis berupa arterosklerosis (Schteingart DE, dalam Hartanto H, Susi N, Wulandari P, Mahanani DA, 2005).

Pendekatan non farmakologis biasanya dilakukan sebagai langkah awal penanganan DM berupa terapi nutrisi, kegiatan jasmani, penurunan berat badan, bila langkah pertama belum tercapai, baru dilanjutkan dengan penggunaan obat farmakologis (Soegondo, 2007 dalam Feranosa P. (2009).

\section{BAHAN DAN ALAT}

\subsection{Bahan}

Bahan-bahan yang digunakan dalam penelitian ini, meliputi: daun cincau hijau, pandan wangi, kayu manis, gula stevia, aquades (air), kragenan.

\subsection{Alat}

Alat yang digunakan meliputi: Gelas ukur (pyrex), timbangan analitik (Denver Instrument), panci, sendok, thermometer (pyrex), refrigerator (SHARP), 
pisau, baskom, gelasplastik, kertas atau kain saring, kompor gas dan gas, alat pengukur kadar gula darah dan spuit $10 \mathrm{ml}$.

\section{METODE}

Sejalan dengan tujuan penelitian yang ingin dicapai, maka metode penelitian ini meliputi tahapan berikut:

\subsection{Tahap Pembuatan Formula Jelly drink}

Formula jelly drink berdasarkan 3 formulasi daun cincau hijau, daun pandan wangi dan kayu manis seperti pada tabel 1 .

Tabel 1 Perbandingan Formula untuk Uji Panel Peringkat

\begin{tabular}{lccc}
\hline \multicolumn{1}{c}{ Bahan } & $\begin{array}{c}\text { Formula 1 } \\
(\mathbf{v} / \mathbf{v} / \mathbf{v})\end{array}$ & $\begin{array}{c}\text { Fomula 2 } \\
(\mathbf{v} / \mathbf{v} / \mathbf{v})\end{array}$ & $\begin{array}{c}\text { Formula 3 } \\
(\mathbf{v} / \mathbf{v} / \mathbf{v})\end{array}$ \\
\hline Cincau hijau & $90 \%$ & $80 \%$ & $75 \%$ \\
Pandan wangi & $10 \%$ & $20 \%$ & $25 \%$ \\
Kayu manis & $0,5 \%$ & $0,5 \%$ & $0,5 \%$ \\
Gula stevia & $0,5 \mathrm{gr}$ & $0,5 \mathrm{gr}$ & $0,5 \mathrm{gr}$ \\
\hline
\end{tabular}

\subsection{Tahap Uji Organoleptik}

Uji organoletik bertujuan untuk memilih formula jelly drink yang dilakukan oleh 20 panelis. Formula terpilih kemudian diintervesikan ke responden.

\subsection{Tahap Pemilihan Responden}

Sebanyak 22 responden dipilih melalui skrining yang memenuhi kriteria inklusi. Responden dibagi menjadi dua, yaitu 11 responden kelompok intervensi dan 11 responden kelompok kontrol

\subsection{Tahap Intervensi.}

Responden diberikan jelly drink sebanyak $200 \mathrm{ml}$ selama satu minggu, dua minggu dan tiga minggu.

\subsection{Tahap Pengambilan Darah dan Uji Kadar Glukosa Darah}

Resonden diambil darahnya sebanyak $7 \mathrm{ml}$ pada hari ke 0 , hari ke7, hari ke 14 dan hari ke 21. Pengambilan darah responden dilakukan oleh tenaga analis kesehatan yang selanjutnya dilakuakan pengukuran kadar glukosa darah.

\subsection{Tahap analisis.}

Data yang terkumpul kemudian dilakukan uji statistik dengan komputer program SPSS versi 16 dengan uji ANOVA.

\section{HASIL PENELITIAN}

\subsection{Analisis Uji Organoleptik Hedonik}

Formula jelly drink diujikan kepada 20 panelis untuk mencicipi, menilai dan menentukan formula terpilih. Hasil uji tampak pada tabel 2.

Tabel 2 Rerata Uji Panel Peringkat Kesukaan

\begin{tabular}{cccccccc}
\hline \multirow{3}{*}{ Kesukaan } & \multicolumn{2}{c}{ Formula 1 } & \multicolumn{2}{c}{ Formula 2 } & \multicolumn{2}{c}{ Formula 3 } & \\
\cline { 2 - 7 } & Mean & SD & Mean & SD & Mean & SD & pvalue \\
\cline { 2 - 7 } & 2,50 & 0,60 & 1,70 & 0.80 & 1,85 & 0,81 & 0,020 \\
\hline
\end{tabular}

Tabel 2 tampak bahwa formula 1 merupakan formula yang paling banyak dipilih relawan dengan rerata 2,50. Artinya formula 1 dapat dilanjutkan untuk penelitian selanjutya. 


\subsection{Analisis Kadar Glukosa Darah Pada Kelompok Kontrol dan Intervensi}

Hasil pengukuran kadar glukosa darah sebelum (pre-test) dan sesudah perlakuan (post-test) pada kelompok kontrol yang diberikan cincau hijau tampak pada tabel 3.

Tabel 3 Distribusi Nilai Sentral Pengukuran Kadar Glukosa Darah pada Kelompok Kontroldan Intervensi

\begin{tabular}{lccccc}
\hline \multirow{2}{*}{\multicolumn{1}{c}{ Variabel }} & N & \multicolumn{2}{c}{ Kelompok Kontrol } & \multicolumn{2}{c}{ Kelompok Intervensi } \\
\cline { 3 - 6 } & & Mean & Min-Max & Mean & Min-Max \\
\hline Pre-tes hari ke-0 & 11 & 242,64 & $114-366$ & 294,45 & $212-481$ \\
Post-test hari ke-7 & 11 & 233,64 & $133-416$ & 267,82 & $136-441$ \\
Pos-test hari ke-14 & 11 & 196,45 & $120-396$ & 214,36 & $128-389$ \\
Post-test hari ke-21 & 11 & 173,09 & $126-285$ & 158,27 & $102-319$ \\
\hline
\end{tabular}

Tabel 3 tampak bahwa rerata kadar glukosa darah pre test kelompok kontrol sebesar 242,64 dengan kadar glukosa darah minimum 114 dan maksimun 366. Penurunan kadar glukosa darah mulai tampak pada hari ke 14 dan 21. Pada pengukuran hari ke 21 kadar glukosa darah dengan rerata 173,09, dengan kadar glukosa darah minimum 126 dan maksimum 285. Dapat disimpulkan bahwa kadar glukosa darah kelompok kontrol cenderung mengalami penurunan.

Pada kelompok intervensi kadar glukosa darah pada hari ke 0 atau pre test sebesar 294,45 dengan kadar glukosa darah minimum 212 dan maksimum 481. Penurunan kadar glukosa darah mulai tampak pada pengukuran hari ke 7, 14 dan 21. Pada pengukuran hari ke 21 kadar glukosa darah memiliki rerata 158,27, minum kadar glukosa darah 102 dan maksimum 319. Dapat disimpulkan bahwa kadar glukosa darah pada kelompok intervensi secara bermakna mengalami penurunan.

Penurunan kadar glukosa darah pada kelompok kontrol dapat dilihat pada grafik sebagai berikut:

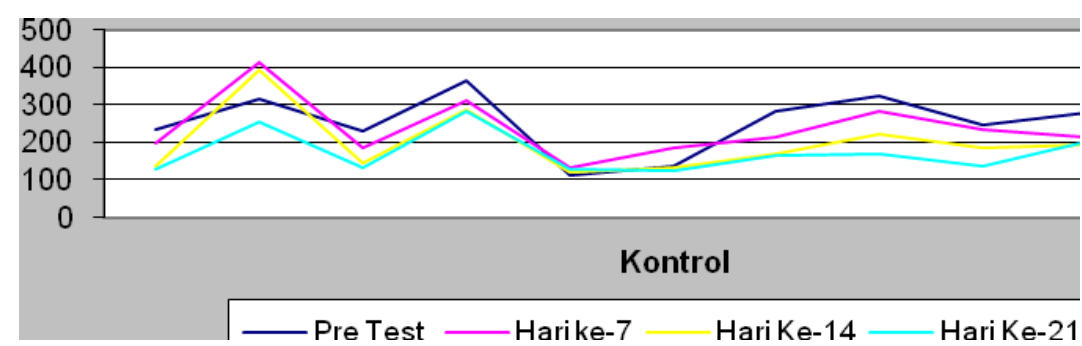

Gambar 1 Grafik Penurunan Kadar Glukosa Darah pada Kelompok Kontrol

Gambar 1 tampak bahwa penurunan kadar glukosa darah cenderung mengalami penurunan pada pengukuraan hari 7, 14 dan 21.

Penurunan kadar glukosa darah pada kelompok intervensi dapat dilihat pada grafik sebagai berikut:

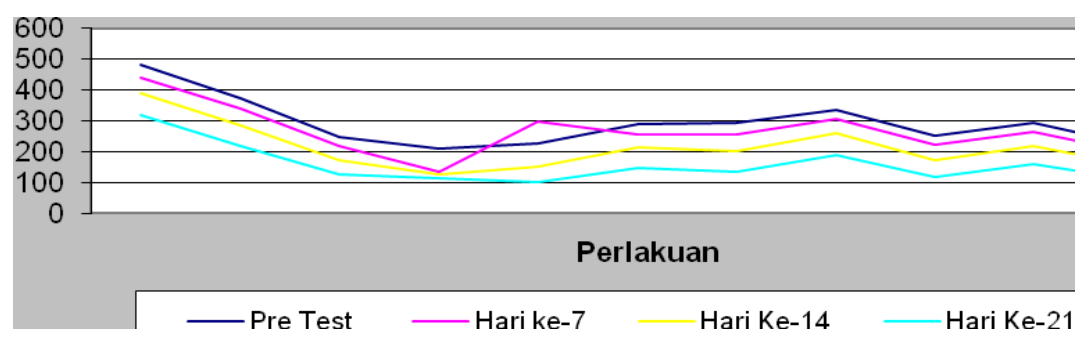

Gambar 2 Grafik Penurunan Kadar Glukosa Darah Pada Kelompok Intervensi 
Gambar 2 tampak bahwa penurunan kadar glukosa darah mengalami penurunan pada pengukuraan hari 7, 14 dan 21 .

\subsection{AnalisisPengaruhCincau Hijau dan Jelly drink Terhadap Kadar Gklukosa Darah}

6.8.1. Pengaruh Cincau Hijau Pada Kelompok Kontrol

Pengaruh cincau hijau pada kelompok kontrol diukur sebanyak 4 kali uji, yaitu pada hari ke 0 (pre test), post test hari ke 7, 14 dan 21. Hasil tersebut tampak pada tabel 4 .

Tabel 4 Pengaruh Cincau Hijau Terhadap Kadar Glukosa Darah pada Kelompok Kontrol

\begin{tabular}{|l|c|c|c|c|}
\hline \multicolumn{1}{|c|}{ Perlakuan } & Mean & SD & F & p value \\
\hline Pre-tes hari ke-0 & 242,64 & 84,814 & 2,037 & 0,124 \\
Post-test hari ke-7 & 233,64 & 77,790 & & \\
Pos-test hari ke-14 & 196,45 & 81,894 & & \\
Post-test hari ke-21 & 173,09 & 53,409 & & \\
\hline
\end{tabular}

Tabel 4 tampak hasil uji ANOVA diperoleh $\rho$ value sebesar 0,124 > 0,05 , sehingga Ho diterima yang berarti tidak ada perbedaan yang bermakna pengukuran kadar glukosa darah pada kelompok kontrol yang diberikan cincau hijau pada pre test, hari ke 7, 14 dan 21.

6.8.2. Pengaruh Jelly Drink Terhadap Kadar Glukosa Darah pada Kelompok Intervensi

Pengaruh jelly drink pada kelompok intervensi diukur sebanyak 4 kali uji, yaitu pada hari ke 0 (pre test), post test hari ke 7, 14 dan 21. Hasil tersebut tampak pada Tabel 5.

Tabel 5 tampak hasil uji ANOVA diperoleh $\rho$ value sebesar $0,001<$ 0,05, sehingga Ho ditolak yang berarti ada perbedaan yang bermakna pengukuran kadar glukosa darah pada kelompok intervensi yang diberikan jelly drink pada pre test, hari ke 7, 14 dan 21

Tabel 5 Pengaruh Jelly drink Terhadap Kadar Glukosa Darah pada Kelompok Intervensi

\begin{tabular}{|c|c|c|c|c|}
\hline Perlakuan & Mean & SD & $\mathbf{F}$ & $\rho$ value \\
\hline Pre-tes hari ke-0 & 294,45 & 79,267 & 7,147 & 0,001 \\
\hline Post-test hari ke-7 & 267,82 & 80,130 & & \\
\hline Pos-test hari ke-14 & 214,36 & 74,650 & & \\
\hline Post-test hari ke- 21 & 158,27 & 64,259 & & \\
\hline
\end{tabular}

\section{PEMBAHASAN}

\subsection{Uji Organoleptik Hedonik}

Pengukuran uji organoleptik dilakukan oleh 20 relawan, untuk menilai formula jelly drink cincau hijau. Relawan diminta mencicipi dan menilai jelly drink yang meliputi rasa, tekstur dan aroma.

Hasil panelis uji organoleptik hedonik membuktikan bahwa formula 1 terpilih untuk dilakukan uji selanjutnya. Formula 1 memperoleh nilai panelis tertinggi pada atribut aroma sebanyak 55\%, kemudian atribut rasa sebanyak 50\% dan atribut tekstur sebanyak 40\%. Formula 1 juga memperoleh rerata 2,5 dan $\mathrm{p}$ vlue $=0,020$. Berdasarkan hal tersebut berarti formula 1 dengan perbandingan $90 \%$ cincau hijau, 
$10 \%$ pandan wangi, 0,5\% kayu manis dan 0,5 gr gula stevia dapat merupakan formula terpilih, sehingga dapat dilanjutkan uji selanjutnya.

\subsection{Pengaruh Cincau Hijau terhadap Kadar Glukosa Darah pada Kelompok Kontrol}

Pengukuran kadar glukosa darah dilakukan sebanyak 4 kali, yaitu pada hari ke0 (pre-test), pada post-test hari ke-7, hari ke-14 dan hari ke-21. Pengukuran ini dilakukan untuk mengetahui penurunan kadar glukosa darah setelah perlakuan baik pada kelompok kontrol.

Pada kelompok kontrol diberikan cincau hijau sebanyak $200 \mathrm{ml}$ dengan penambahan gula stevia sebanyak 0,5 gram. Penurunan kadar glukosa darah terjadi akibat perlakuan dibandingkan kadar gula darah sebelum perlakuan pada hari ke-0. Meskipun secara signiffikan penurunan kadar glukosa darah lebih tampak pada hari ke-14 dan hari ke-21.

Penurunan kadar glukosa darah ini terjadi karena pengaruh flavanoid yang terkandung dalam cincau hijau. Hasil penelitian PrajwalitaR.R, Rizca D.J, Tri D.W (2015), membuktikan bahwa teh herbal berbahan dasar daun cincau hijau mengandung flavanoid sebanyak $392.67 \mathrm{Lg}$ CEQ/m.dan antioksidan sebanyak $68,63 \%$. Hasil ini juga membuktikan bahwa teh herbal berbasis cincau hijau memberikan pengaruh nyata terhadap penurunan kadar glukosa darah tikus witsar jantan. Ali M.H (2012) juga membuktikan berdasarkan uji laboratorium ternyata daun cincau hijau mengandung flavanoid dan alkaloid.

Flavanoid merupakan antioksidan yang dapat menurunkan stress oksidatif dan mengurangi ROS (Reaktive Oxygen Species). Hal ini akan menimbulkan efek protektif terhadap sel beta pankreas dan meningkatkan sensitivitas insulin (Kaneto et al, 1999 dalam Feranosa, 2009). Mekanisme ini melalui dua jalur utama. Jalur pertama sebagai peredam radikal bebas secara langsung dengan menyumbangkan atom hidrogenya. Flavanoid akan teroksidasi oleh radikal menjadi senyawa yang lebih stabil. Jalur kedua melalui Chelaying ion logam (Nijveldt et al; Suhartono, 2004 dalam Feranosa P. (2009)

Flavanoid merupakan penghambat yang kuat terhadap GLUT 2 (suatu lintasan absorbsi glukosa dan fruktosa pada membran usus), dengan mekanisme yang bersifat kompetitif. Hal ini menyebabkan pengurangan penyerapan glukosa dan fruktosa dari usus, sehingga kadar glukosa darah turun (Jian Song et al, 2002; Oran et al, 2007 dalam Feranosa P. (2009). Mekanisme ini diasumsikan bahwa penghambat GLUT 2 usus dapat menjadi terapi potensial untuk mengontrol kadar gula darah (Kellet and Edith, 2005 ; Feranosa P. (2009)

Flavanoid memiliki mekanisme dalam penghambatan fosfodiesterase, sehingga kadar cAMP dalam sel beta pankreas meninggi. Hal ini akan merangsang sekresi insulin melalui jalur Ca (Ohno et al, 1993 dalam Feranosa P. (2009). Peningkatan kadar cAMP akan menyebabkan penutupan kanal K+ATP dalam membran plasma sel beta. Keadaan ini akan menyebabkan terjadinya depolarisasi membran dan membukanya saluran $\mathrm{Ca}$ (Calsium), sehingga mempercepat masuknya ion $\mathrm{Ca}$ ke dalam sel. Peningkatan ion $\mathrm{Ca}$ dalam sitoplasma sel beta ini akan menyebabkan sekresi insulin oleh sel beta pankreas (Sato et al, 1999; Yamada et al, 2002; Feronesa, 2009). 


\subsection{Pengaruh Jelly Drink terhadap Kadar Glukosa Darah pada Kelompok Intervensi}

Pada kelompok intervensi yang diberikan jelly drink cincau hijau, pandan wangi dan kayu manis membuktikan bahwa pada hari ke-7 sudah tampak penurunan kadar glukosa darah dan paling besar penurunannya pada hari ke-21.

Perbedaan penurunan kadar glukosa darah pada kelompok intervensi ternyata pada hari ke-7 pengukuran . Penurunan tersebut dari rerata 242,82 pada pre-test menjadi 219,18 pada post-test hari ke-7 dengan pvalue 0,025 .

Penurunan kadar glukossa darah pada kelompok intervensi disebabkan oleh kandungan flavanoid yang terdapat pada cincau hijau dan ditambah dengan flavanoid yang terkandung dalam kayu manis dan pandan wangi.

Soemardini dkk (2011), membuktikan kayu manis telah diteliti beberapa kali dapat menurunkan kadar glukosa darah. Selain itu, kulit kayu manis mengandung alkaloid, flavonoid, dan minyak atsiri yaitu kamfer, safrol, eugenol, sinamaldehid, sinamilasetat, terpen, sineol, sitral, sitronelal, polifenol dan benzaldehid. Kayu manis juga mengandung oleorin yang dipakai dalam industri makanan atau minuman untuk memberikan rasa segar.

Daun pandan wangi banyak digunakan sebagai obat tradisional untuk meredakan sakit gigi, rematik, diuretik, antiinflamasi, dan menurunkan kadar gula darah dalam tubuh atau efek hipoglikemik (Asmain A.B., 2010, dalam Winda Rein .N.T, Tri Dewanti W., (2014).

7.4. EfektivitasPenuruan Kadar Glukosa Darah pada Kelompok Kontrol dan Kelompok Intervensi

Penurunan kadar glukosa darah pada kelompok kontrol terjadi secara bermakna pada pengukuran hari ke-14. Sedangkan pada kelompok intervensi penurunan kadar glukossa darah mulai terjadi pada pengukuran hari ke-21 .

Penurunan kadar glukossa darah pada kelompok intervensi disebabkan oleh kandungan flavanoid yang terdapat pada cincau hijau, kayu manis dan pandan wangi.

Soemardini dkk (2011), membuktikan kayu manis telah diteliti beberapa kali dapat menurunkan kadar glukosa darah. Selain itu, kulit kayu manis mengandung alkaloid, flavonoid, dan minyak atsiri yaitu kamfer, safrol, eugenol, sinamaldehid, sinamilasetat, terpen, sineol, sitral, sitronelal, polifenol dan benzaldehid. Kayu manis juga mengandung oleorin yang dipakai dalam industri makanan atau minuman untuk memberikan rasa segar.

Daun pandan wangi banyak digunakan sebagai obat tradisional untuk meredakan sakit gigi, rematik, diuretik, antiinflamasi, dan menurunkan kadar gula darah dalam tubuh atau efek hipoglikemik (Asmain A.B., 2010, dalam Winda Rein .N.T, Tri Dewanti W., (2014).

Berdasarkan hal tersebut, berarti penurunan kadar glukosa darah lebih efektif pada kelompok intervensi yang diberikan jelly drink dibanding kelompok kontrol yang hanya diberikan cincau hijau

\subsection{Jelly Drink Cincau hijau, Pandan Wangi dan Kayu Manis sebagai Pangan Fungsional}

Beberapa penelitian membuktikan bahwa jelly drink berbahan dasar cincau hijau dapat berfungsi sebagai pangan fungsional. Nur K, dan Leily A (2014), membuktikan bahwa produk jelly drink tiap 100 gram basis basah mengandung 
kadar air 98,54\%, abu 0,29\%, Protein 0,13\%, Lemak 0,10 gr, Karbohidrat 0,05\%, kadar serat 2 gr.

Kayu manis juga mengandung protein, karbohidrat, vitamin (A, C, K, B3), mineral seperti kalsium, zat besi, magnesium, mangan, fosfor, sodium, zinc dan kolin (Meena V., Sree S.N., Surya P.D.V., and Sumanjali A., 2012) dalam Winda R.N.T, Tri Dewanti W., (2014).

Daun pandan secara luas telah digunakan sebagai pemberi rasa pada makanan dan minuman dan dapat meningkatkan nafsu makan.

Menurut Widyaningsih, TD.,(2006) beberapa persyaratan pangan fungsional adalah merupakan produk pangan, layak dikonsumsi sebagai diet atau menu seharihari, mempunyai fungsi tertentu saat dicerna serta memberikan peran dalam proses tubuh tertentu, jelas sifat fisik dan kimianya aman dikonsumsi, kandunganya tidak menurunkan nilai gizinya

Menurut Widyaningsih (2007), syarat jelly yang baik adalah transparan, memiliki aroma dan rasa yang asli. Sedangkan menurut Triyani (2006), tekstur yang dinginkan pada minuman jelly adalah mantap saat dikonsumsi menggunakan bantuan sedotan mudah hancur, namun bentuk gelnya masih terasa di mulut.

Jelly drink cincau hijau, pandan wangi dan kayu manis memenuhi persyaratan baik kandungan gizinya maupun daya terimannya oleh relawan dari uji organoleptik hedonik. Selain itu, jelly drink berbahan dasar cincau hijau mengandung serta cukup tinggi dan rendah lemak. Berdasarkan hal tersebut, maka jelly drink ini dapat digunakan sebagai pangan atau minuman fungsional berbasis terapi pada penderita diabetes melitus.

\section{KESIMPULAN}

8.1. Formula jelly drinkterpilihadalah formula 1 dengan perbandingan cincau hijau (90\%), pandan wangi (10\%), kayu manis $0.5 \%$ dan gula stevia 0,5 gram.

8.2. Pemberianjelly drinkcincau hijau, pandan wangi dan kayu manis secara bermakna menurunkan kadar glukosa darah antara kelompok intervensi

8.3. Pemberiancincauhijaucenderungmenurunkan kadar glukosa darah pada kelompok kontrol, namun tidak terdapat perbedaan yang bermakna antara kelompok

8.4. Jelly drink pada kelompok intervensi lebih efektif menurunkan kadar glukosa darah disbanding kelompok kontrol

8.5. Jelly drink cincau hijau, pandan wangi dan kayu manis dapat digunakan sebagai pangan fungsional berbasis terapi

\section{SARAN}

9.1. Perlu dilakukan penelitian lanjutan untuk menguji daya terima masyarakat yang lebih luas pada produk jelly drink cincau hijau serta untuk menguji waktu simpan produk atau daya tahan produk.

9.2. Perlu dilakukan penelitian lanjutan untuk menentukan dosis flavanoid yang efektif menurunkan kadar glukosa darah

9.3. Perlu penelitian lanjutan produk jelly drink untuk mencegah atau mengobati penyakit degeratif lain seperti hipertensi, kolesterol dan sejenisnya. 


\section{DAFTAR PUSTAKA}

Ali, M.H., 2012, Uji Aktivitas Antioksidan Ekstrak dan Fraksi daun Cincau Hijau Rambat dan Identifikasi Golongan Senyawa dari Fraksi paling Aktif, Skripsi, F-MIPA, UI, Jakarta.

Anderson R.F., Fisher L.J., Hara Y., Harris T., Mak W.B., and Melton L.D. (2001). Green Tea Catechin Partially Protect DNA From OH Radical-Induced Strand Break And Base Damage Through Fast Chemical Repair of DNA Radicals. Carcinogenesis 22: 11891193

Angelona. M, Hartati. S., Dewijayanti. I.D., Banjarnahor. S.D.S, dan Meilawati. L, 2008. Penentuan LD50 Daun Cinco (Cyclea Barbara Miers) pada Mencit, Makara, Sains, Vol.12,No.1: 23-26

Chalid, Sri Yadial, 2003. Pengaruh Ekstrak Cincau Hijau Cyclea barbaraL. Miers terhadap Aktivitas Enzim Superoksida Dismutase dan Katalase pada Mencit C3H Bertumor Kelenjar Susu. Tesis, Program Pascasarjana IPB.

Fatihamin, M.N, Suhaila. M, Nor. A.1., and Razali I, 2008. Antioxidative Properties of Pandanus amaryllifolius Leaf Extracts in Accelerated Oxidation and Deep Frying Studies. Food Chemistry. vol 110 Issue 2.

Feranosa P. (2009), Pengaruh pemberian buah naga merah terhadap kadar glukosa darah Tikus putih yang diinduksi aloksan, Skripsi, FK-Universitas Sebelas Maret, Surakarta, 2009

Fitriana S, Leiley A, dan Karina R.E. 2014, Minuman Cincau Hijau dapat Menurunkan Tekanan Darah pada Wanita Dewasa penderita Hipertensi Ringan dan Sedang, Jurnal Gizi Pangan, November 2014, 9(3):2003-210.

Glicksman, M. 1993. Hydrocoiloid. Volum ke-1. CRC Press Inc. Boca Ratton. Florida.

Guo Q., Zhao B., Li M., Shen S., and Xin W. (1996). Studies on Protective Mechanisms of Four Components of Green Tea Polyphenols Againts Lipid Peroxidation in Synaptosomes. Biochemica et Biophysica Acta

Kementerian Kesehatan Republik Indonesia, 2010. Prevalensi Diabetes Meilitus di Indonesia. http://depkes.go.id/prevalensi-dibetes-melitus-di-Indonesia.html. diakses tanggal 15 Agustus 2016.

Laksanamai V. and Ilangantileke S. (1993). Comparison of Aroma Compound (2-Acetyl-1Pyrroline) in Leaves from Pandan (Pandanus amaryllifolius) and Thai Fragrant Rice (Kao Dawk Mali-105). Cereal Chem 70:381-384

Lokesh D, Amitsankar D, 2012., Pharmacognostical evaluation and establishment of quality parameters of medical plants of north-east india used by folklore healers for treathment of hypertension., J Pharmacogn.

Malik VS, Popkin BM, Bray GA, \& Hu FB. (2010). Sugar sweetened beverages, obesity, type 2 diabetes mellitus, and cardiovascular disease risk. Circulation.

Miladiyah I., Siregar. I.M., 2011. Protective effects of Cyclea barbata Miers leaves againts aspirin-induced gastric ulcer in mice. Universa medicina 
Muchtadi D. (1989). Aspek Biokimia dan Gizi dalam Keamanan Pangan. Dalam Ferdiana A. 2004. Evaluasi Mutu Minuman Teh-Kayu Manis Selama Penyimpanan. Skripsi. IPB.Bogor

Naithani V., Nair S., and Kakkar P. (2006). Decline in Antioxidant Capacity of Indian Herbal Teas During Storage and Its Relation To Phenolic Content. Food Research International 39:176-181

Nur Khoiriyah, Indah Purnamasari, maryam Nabila., 2014, Potensi Jelly Cincau dalam Menurunkan Kadar Malondialdehyde dan C-reactive Protein serta Memperbaiki Profil Lipid Darah, PKM, ITB.

Nurdin et al. 2008. Pengaruh Pemberian Bubuk Ekstrak Cu-Turunan Klorofil Daun Cincau (Premna oblongifolia Merr.) terhadap Profil Lipid Darah Kelinci. Jurnal, Media Gizi dan Keluarga.

Pocock, S. 2008. Clinical Trials: A Practical Approach. Chichester: John Wiley \& Sons. p. $128-129$.

Prajwalita R.R., Rizca W.J, Tri Dewanti W., 2015, Pengaruh Teh Herbal Berbasis Daun Cincau Hijau terhadap Glukosa Darah dan Profil Lipid Tikus Hiperglikemia., Jurnal Pangan dan Agroindustri Vol 3 No 3, Juli 2015.

Pratiwi, I.Y, 2011. Pengaruh variasi Maltodekstrin terhadap kualitas Minuman Serbuk Instan kayu Manis, Skripsi, UAIY, Yogyakarta.

Putri P.A, Shelly A, Tri Dewanti W, 2015., Pengaruh Penambahan Pandan Wangi dan kayu manis pada Teh Herbal Kulit Salak bagi Penderita Diabetes, Jurnal pangan dan Agroindustri Vol No 1, Januari 2015

Riset Kesehatan Dasar (RISKESDAS, 2013). Prevlensi Diabetes.

Rohmawati E. (1995). Skrining Kandungan Kimia Daun Pandan serta Isolasi dan Identifikasi Alkaloidnya. Dalam Rina M. dan Endang P.A. 2012. Potensi Daun Pandan (Pandanus amaryllifolius) dan Mangkokan (Notophanax scutellarium) Sebagai Repelen Nyamuk Aedes Albopictus. ASPIRATOR 4(2), 2012:85-91

Salzler MJC, Crawford JM, Kumar V. Pankreas. Dalam: Asroruddin M, Hartanto H, Darmaniah N. buku ajar patologi edisi ke-7 (terjemahan). Jakarta: EGC; 2007. hlm. 71133.

Schteingart .E, Pankreas: Metabolisme Glukosa dan Diabetes melitus. Dalam price SA, Wilson LM. Patofisiologi Konsep Klinis Proses-proses Penyakit. 6th edition, jakarta, 2003

Silva, M.L, 2004. Diabetes Means Siphon Insulin Comes from the Island. http://www.apol.net/dightonrock/dibetes_history.html. diakses 3 Agustus 2016.

Soekarto, S.T, (1995). Penilaian Organoleptik untuk Industri Pangan dan hasil Pertanian, Bhatara Karya Aksara. Jakarta

Soemardini., Nugroho, E.a, M, 2011., Pengaruh Bubuk Kayu Manis (Cinnnamomum burmanii) terhadap kadar Kolesterol Rattus norvegicus strain Wistar Tyoe-2-Diabetes. Artikel Tugas Akhir Fakultas Kedokteran Brawijaya. 
Triyani (2006). Jelly Drink. Volume 1 dan 2. Jakarta : UI Press

Vox D. (2011). Drinking Herb Teas: The Various Health Benefits. http://ezinearticles.com/?Drinking-Herb-Teas:-The-Various-Health Benefits\&id=6681488. Tanggal akses: 03/02/2016

Widyaningsih T.D, 2006. Pangan Fungsional: Makanan untuk Kesehatan. Universitas Brawijaya. Malang.

Widyaningsih T.D. (2006). Pangan Fungsional: Makanan Untuk Kesehatan. Universitas Brawijaya. Malang

Widyaningsih T.D. (2007). Olahan Cincau Hitam. Trubus Agrisarana. Surabaya

Winda R.N.T, Tri Deanti W., 2014, Potensi Cincau Hitam, Daun Pandan dan kayu manis sebagai Bahan Minuman Herbal Fungsional. Jurnal Pangan dan Agroindustri Vol.2 No 4 p. 128-136, Oktober 2014. 